\title{
The Methodology of Melioration and Restoration of the Largest Dumps of the Most Coal Basin
}

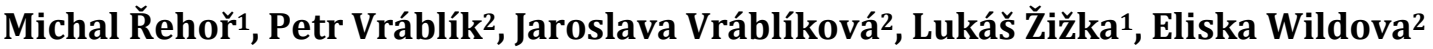 \\ ${ }^{1}$ Research Institute for Brown Coal in Most, Most, Czech Republic \\ ${ }^{2}$ Department of Natural Sciences, Faculty of Environment, J. E. Purkyně University in Ústí nad Labem, Ústí nad Labem, Czech \\ Republic \\ Email: Wildova.Eliska@gmail.com
}

How to cite this paper: Řehoř, M., Vráblík, P., Vráblíková, J., Žižka, L. and Wildova, E. (2017) The Methodology of Melioration and Restoration of the Largest Dumps of the Most Coal Basin. Journal of Environmental Protection, 8, 1583-1594. https://doi.org/10.4236/jep.2017.813097

Received: November 13, 2017 Accepted: December 17, 2017 Published: December 21, 2017

Copyright $\odot 2017$ by authors and Scientific Research Publishing Inc. This work is licensed under the Creative Commons Attribution International License (CC BY 4.0).

http://creativecommons.org/licenses/by/4.0/

\begin{abstract}
Reclamations of dumps in the Most Basin that is located in the North Bohemia consist of restoration of extremely unfavourable properties of rocks that are poured down onto the dump body. These rocks come from the surface layer and the layer where coal bed is present. Sands, clay sands and kaolin (illitic clays) are the main components that occur in the material. Other components are predominantly organic (coal) mass, siderite and pyrite. This report briefly summarizes the history and present of ore, non-metallic and coal mining in the region and addresses in detail the issue of moderating the consequences of mining, which is one of the principal activities of the Research Institute for Brown Coal, j.s.c. in Most. The concept of landscape reclamation in the largest dumps after mining ends, the technical reclamation methodology and the well considered use of fertilizable soil are main results presented in this article.
\end{abstract}

\section{Keywords}

Land Use, Coal Mining, Restoration, Melioration, Dump

\section{Introduction}

The area of interest lies on the border of the oceanic and continental climate. For the basin part of the area is a characteristic the inverse states where the cold air and low-laid clouds capture the sun's radiation (especially in winter). Due to rainfall shadow that is caused by the Ore Mountains, the basin has lower cloudiness, low rainfall, and higher temperature fluctuations, closer to the continen- 
tal climate, while the mountainous areas are defined by ocean climate [1]. The North-Bohemian Basin area is known for its largest Czech brown coal deposit. Over $70 \%$ brown coal reserves are currently being extracted in the Most Basin. The opencast quarries caused extensive damage to the landscape. Reclamation works became significant in order to restore the newly created anthropogenic formations and integrate them into the surrounding environment. The rocks that are poured down onto the dump body are mechanically unstable with respect to wind and water erosion and during weathering they develop an unfavourable, phytotoxic nature, due to the influence of $\mathrm{SO}_{3}$ and $\mathrm{Al}$ ions. The external and internal dumps in open pit mines are significant part of the NorthBohemian landscape sustained by excavation. Their rapid preparation and gradual integration into area's ecosystem is of interest to the region's citizens and mining companies. The paper briefly summarizes the methodology of restoration of the largest dumps in the Most Coal Basin and the results of analyses and evaluation of samples taken in restored localities of the Radovesice dump, Strimice dump, Ruzodol dump and the internal dump of the Bilina mine. An example of modern non-traditional restoration methods is the restoration of internal dump of the Bilina mine (application of power plant stabilizer). According to observations and results of sample analyses, the restoration methods were selected to imitate the effect of erosion, and amend the chemistry and physical composition of the surface of the Radovesice and Strimice dumps. The application of marlites and bentonite prevent the unfavourable weathering processes on dump surface. The substitution of Quaternary sediments was formed here artificially. The need for ploughing in marlite, and the application of organic substrates and vegetation preparation was demonstrated in the Radovesice dump. The suitability of backfilled rocks for restoration purposes was demonstrated in the Ruzodol dump. Brown coal is mined in four general mining localities: Vrsany, CSA, Bilina and Libous. Those quarries differ in geological terms, and partially also in the parameters of acquired coal. That requires a slightly different methodology of extraction and reclamation. The Vrsany and CSA mines are currently the principal mining localities owned by the mining company Mostecká mining company, a.s. and the Bilina and Libous mines are owned by the mining company North-Bohemian mines, a.s.

\section{Materials and Methods}

\subsection{History and Present of Non-Coal Mining in the Region}

There were three large ore districts in the North-Western Bohemia region. Jachymov, as the most important, used to be a great deposit of Ag-Bi-Co-Ni formation. Silver extraction culminated in the $16^{\text {th }}$ century. Silver Jachymov thalers have given the name to the American dollar. After exhausting silver mineralization, nonferrous metals were extracted at the site, followed by uranium ore in the last phase. Today Jachymov belongs among leading Czech spas. Krupka was the oldest ore deposit of $\mathrm{Sn}-\mathrm{Cu}-\mathrm{Mo}$ formation already known in the $13^{\text {th }}$ century. 
The mining of tin culminated in the second half of the $15^{\text {th }}$ and $16^{\text {th }}$ century, but now the deposits have been abandoned. Cínovec was the last very important ore site. It was a classical $\mathrm{Sn}-\mathrm{W}-\mathrm{Cu}-\mathrm{Mo}$ formation linked to granite intrusion into the para-series of the Ore Mountains crystalline complex. Today, this deposit has also been abandoned, although the future extraction of lepidolite lithium mica has not been completely ruled out. The region's mining history was highly impacted by the extraction of precious stones. Precious stone deposits mined in the Ore Mountains at the time of Charles IV. and probably also. Rudolf II. period are located in the central part of the Ore Mountains between Vejprty and Chomutov. Amethysts, jaspers and agates from the local sites are linked to quartz-amethyst and quartz-amethyst-haematite hydrothermal lodes. Cibousov is one of the historically significant sites at the bottom of the Ore Mountains. In the $14^{\text {th }}$ century, amethysts and jaspers from this site were used by the emperor Charles IV. for the medieval inlays in the Saint Cross Chapel at Karlstejn and Saint Wenceslas Chapel in the Saint Vitus Cathedral. The site, forgotten for centuries, was rediscovered in the year 1982. Today it has only historical and mineralogical significance. Pyrope is another precious North-Western Bohemian stone, found since the early middle Ages on the Southern slopes of the Central Bohemian Uplands. Pyrope, or Czech garnet, belongs to the magnesium variety of garnet. The mainly native rocks are pyroxene peridots and kimberlites. The classic dark sanguine colour of pyrope is caused by the admixture of chromic oxide, whose content is almost $2 \%$. Minable accumulations currently occur in Quaternary deposits in Chrastany, Dremcice and Trebivlice. Total resources can be estimated to ca 50 years. Today it is the only commercial precious stone of the Czech Republic. Besides Czech garnet, gravel is extracted in the mines of the Czech Bohemian Uplands region. Ceramic and brick materials together with the rocks usable in reclamation are mined as a side product in the North Bohemian Basin. In general terms today non-coal mining, in spite of its famous history, has only small significance in the North-Western Bohemian region.

\subsection{History and Present of Coal Mining and Reclamation in the Region}

The history of coal mining in the region spans hundreds of years. The records in the chronicles from the $14^{\text {th }}-15^{\text {th }}$ century are the proof. At the turn of the $19^{\text {th }}-20^{\text {th }}$ century dozens of deep mines were extracting here, and first small opencast mines started to appear. With such a concentration of mining the North-Western Bohemia has obviously gone down in the history of reclamation, too. These started not only in the North Bohemian Basin but in whole of Bohemia in the year 1908 when a reclamation agency of the municipal agricultural council was established in Duchcov. According to the data of this body 448 ha of total 3372 ha devastated land was reclaimed in the entire district at that time. It mainly concerned smaller areas corresponding to the mining dimensions of that time. Reclamation took place, even later, in a simple undemanding way by the 
recovery of a former field and its cultivation. After the $2^{\text {nd }}$ World War the significance of deep mines gradually decreases and mining starts to be concentrated in small opencast mines. The systematic development of reclamation work takes place in the fifties. In the year 1957, an agricultural and reclamation plant SHD was established in Teplice. The first Reclamation Master Plan was prepared in Mining Projects Teplice in 1959. Reclamation work was provided by the national enterprise North-Bohemian Brown Coal District-Rekultivace in Teplice, Mining Constructions Most and later Reclamation constructions Most which has gradually changed into an investor-supplier organization. Most of the reclamation in the district was carried out with the fellowship of research institutes and Mining Projects Teplice. More demanding technical adaptations were not provided until the sixties. Most of the time, the consequences of old underground mining and the sporadic excavator dumps of small mines were being liquidated. Species of reclamation trees were planted. In the seventies, coal mining gradually became concentrated in several large opencast mines. Each year the areas abandoned due to mining which were gradually reclaimed increased in number. The field was treated before the biological reclamation, fertilizable soil was brought in and the area was drained. Brown coal mining culminated in the eighties, when the annual extracted volumes exceeded 70 million tonnes. Thus reclamation gained a new dimension. Vast areas of dumps were handed over for reclamation, reclamation of high dump bodies became a new issue. In that time selective mining and depositing of soil usable for reclamation was launched. The changes were reflected in the technology with which reclamation work was performed. After the transfer to market economy in the beginning of nineties of the last century the annual, the extraction of brown coal gradually decreased to today's cca 40 million tonnes. Mining was concentrated in four large opencast mines: Libous, Bilina, Vrsany and CSA owned by the mining company North-Bohemian mines, a.s. and Most Coal Company, a.s.. The mine Bilina became the largest opencast mine of the region and the Czech Republic with a cca $5 \mathrm{~km}$ coal face length, cca $200 \mathrm{~m}$ upper bed thickness and cca $30 \mathrm{~m}$ coal seam thickness. At this time,, the reclamation technique and philosophy underwent a quality development. The dump construction is controlled to enable successful reclamation and classification of soil, and its selective depositing has been introduced. Many failed reclamations provided lessons for learning, e.g. Strimice dump reclamation where several new plantings died. Since then the thought-out adaptations of dump surfaces, based on the results and recommendations of the research work, have been taking place. Mining models have been prepared emphasizing wider landscape enhancement concepts of large areas with a connection to the existing ecosystems, but also the planned economic and social structures of the area. That is the example of vast dumps Strimice, Pokrok and Radovesice reclamation. The reclamation plans also include the creation of large bodies of water in the closed down mines. Totally new landscape elements should be formedin this way, with an impact on the environment, and they will still have to be analysed in detail. The first phase of the reclamation work, under the North Bohemian 
Basin conditions, includes the adjustment of the rock environment in the top horizon of the reclamation sites using locally available fertilizable rocks. Scientific biological reclamation focused on the future use of landscape then follows. The success of reclamation work is, to wide extent, dependent on the knowledge of the properties of the overburden rocks from the opencast mines, the research of top horizon in the dump, scientific use of the fertilizable rocks and preparation of a suitable reclamation methodology. The Research Institute of Brown Coal, a.s. deals with this issue and some of the results have been presented in this report. The total status of the area of interest is shown in Figure 1.

\section{Results and Discussion}

\subsection{Properties of the Coal Seam in the Most Basin}

The principal seam with 20 - $40 \mathrm{~m}$ thickness is the only mining seam in the Most Coal Basin. It is mostly formed by brown coal humites which were generated by the carbonization of tertiary peat, shrubs and trees. It is generally divided by scuds into three benches of various qualities. The principal coal seam occurs in various stages. It usually settles as a uniform seam, the thickness of which varies among various parts of the basin. That is the example of Libous and CSA mines. In the Vrsany mine the principal coal seam is divided into several seams. In the Bilina mine, the principal coal seam construction is abnormal, which relates to the settlement peculiarities caused by the deformations taking place after the

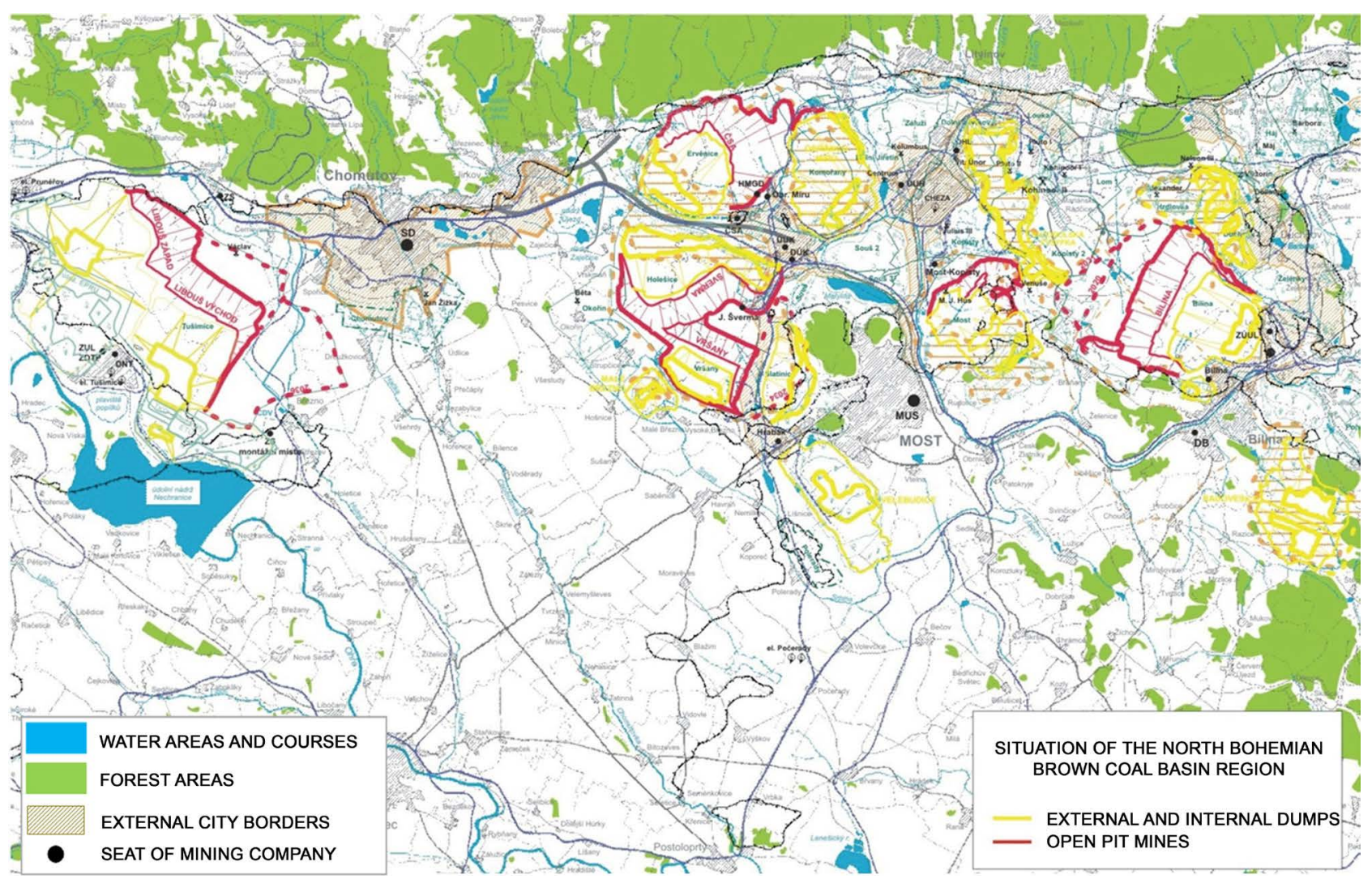

Figure 1. Status of the North-Bohemian Basin area of interest [2]. 
uniform coal seam was formed. That time more or less independent bodies of the coal seam with irregular extent and thickness were formed. Several parts used to be "corrugated" and accompanied with scissor faults. The overburden dead sediments used to be deformed, together with the seam. The occurrence of overburden rocks in the coal seam, mainly in the Bilina mine and in Vrsany, is, to a smaller extent, the consequence of this situation. For that reason we can say there is an increased occurrence of phyto-toxic areas with coal in the top horizon of the external and inner dumps in these mining localities (mainly the Bilina mine). Such areas do not generally occur in the dumps of Libous and CSA mines [3]. From the reclamation perspective, the exposure parts of the coal seam have certain significance, being the source of oxy-humolites, mainly in the Bilina and Vršany mines. Methodology of the reclamation works in the Most Basin is determined by the characteristics of the overburden rocks. This chapter is focused on stratigraphic status properties of the four mining sites with respect to the reclamation efficiency. The Bilina quarry contains quaternary rocks which are suitable for use in reclamation (topsoil, loess, loess loams). The rocks are mined and used as fertilizable rocks. Also grey kaolinite and illite clay stones that occur in the area are also usable. Deeper deposited of overburden rocks, are not usable for reclamation, and the coal clay stones from the seam formation can be rated as phytotoxic. The overburden cuts of the Bilina mine are shown in Figure 2. In the forefront of the Vrsany mine there are also quaternary rocks which are usable for reclamation. Topsoil and mainly very abundant and good quality reserves of loess are selectively mined and used as fertilizable rocks. But the yellow clay of the overburden formation, as well as sands and sandy clay stones of the upper inter deposit, cannot be used for reclamation and the coal clay stones from the bottom inter deposit are virtually phyto-toxic. The situation is better in

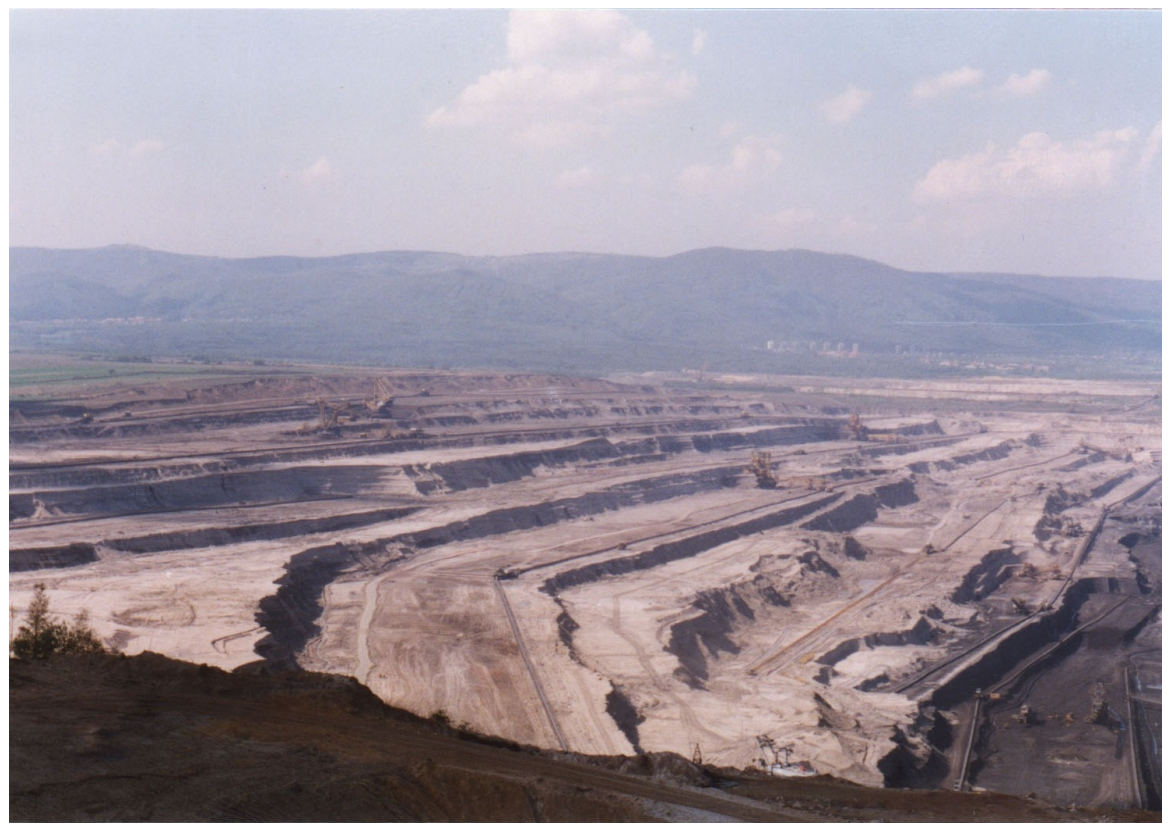

Figure 2. Overburden cuts in the Bilina mine [4]. 
the other two mining localities. In the CSA mine, the quaternary rocks are almost depleted, but the grey clay stones of the overburden massif are, with the exception of the siderite horizon above the head of the coal seam, suitable for use in reclamation. The grey clay stones of the overburden massif that are mined in the Libous quarry are suitable for use in reclamation.

The evaluation proves that the Bilina and Vrsany mines show a similar pattern in terms of availability for reclamation, with rocks not very suitable for reclamation, and that the Libous and CSA mines have better conditions. The reason is the type of settlement at the time of the coal seam deposit, and later on. The mine Libous and Bilina have the largest reserves of topsoil, while the best quality deposit of loess occurs in the forefront of the Vrsany mine. The approach to the research task included the detection of the petrographic and mineralogical properties of stratigraphic horizons lying in the process of the individual opencast mines in the North-Bohemian Basin. The results are illustrated in Table 1. Loess, loess loams and gravel sands are perfect for reclamation, but a mixture of clays makes them rather good for reclamation. Sandy clays, sands and yellow clays have poor restoration usability. The upper horizon is formed by phytotoxic rocks with a mixture of coal and cannot be used for reclamation. The reclamation of opencast mines, internal dumps and the most important external

Table 1. Mineralogical composition and restoration usability of typical overburden rocks.

\begin{tabular}{|c|c|c|c|c|}
\hline Location & Stratigraphic horizon & Type of rock & $\begin{array}{c}\text { Restoration } \\
\text { usability }\end{array}$ & Mineralogy \\
\hline \multirow[t]{4}{*}{ Bílina mine } & Quaternary deposits & $\begin{array}{l}\text { top soil, loess loams, loams, } \\
\text { gravel sands }\end{array}$ & Perfect & $\begin{array}{l}\text { quartz, kaolinite, illite, traces of } \\
\text { anorthoclase, calcite and montmorillonite }\end{array}$ \\
\hline & "Libkovice" overlying strata & grey clays & Good & quartz, kaolinite, illite, traces of siderite \\
\hline & sand-clay strata & sandy clays, sands & Poor & quartz, traces of kaolinite, illite, siderite \\
\hline & overburden rocks of coal bed & sandy clays, sands, coal & Phytotoxic & $\begin{array}{l}\text { quartz, kaolinite, illite, traces of coal and } \\
\text { siderite }\end{array}$ \\
\hline \multirow[t]{4}{*}{ Vrsany mine } & Quaternary deposits & $\begin{array}{l}\text { top soil, loess loams, loesses, } \\
\text { loams, gravel sands }\end{array}$ & Perfect & $\begin{array}{l}\text { quartz, kaolinite, illite, traces of anorthoclase } \\
\text { and calcite }\end{array}$ \\
\hline & Overlying strata & yellow plastic clays & Poor & $\begin{array}{l}\text { quartz, kaolinite, illite, traces of siderite and } \\
\text { goethite }\end{array}$ \\
\hline & overburden rocks of upper coal bed & sandy clays, sands & Poor & $\begin{array}{l}\text { quartz, kaolinite, illite, traces of siderite and } \\
\text { dolomite }\end{array}$ \\
\hline & overburden rocks of main coal bed & sandy clays, sands, coal & Phytotoxic & $\begin{array}{l}\text { quartz, kaolinite, illite, traces of coal and } \\
\text { siderite }\end{array}$ \\
\hline \multirow[t]{2}{*}{ ČSA mine } & Quaternary deposits & loams, clay loams, gravel sands & Good & quartz, kaolinite, illite, traces of anorthoclase \\
\hline & Overlying strata & grey clays & Good & quartz, kaolinite, illite, traces of siderite \\
\hline \multirow[t]{3}{*}{ Libouš mine } & Quaternary deposits & loams, clay loams, gravel sands & Good & $\begin{array}{l}\text { quartz, kaolinite, illite, traces of anorthoclase } \\
\text { and montmorillonite }\end{array}$ \\
\hline & Overlying strata (top of the strata) & yellow plastic clays & Poor & $\begin{array}{l}\text { quartz, kaolinite, illite, traces of } \\
\text { montmorillonite, calcite and siderite }\end{array}$ \\
\hline & Overlying strata & grey clays & Good & quartz, kaolinite, illite, traces of siderite \\
\hline
\end{tabular}


dumps is crucial for integrating the sites damaged by mining into the surrounding ecosystem.

\subsection{Strimice Dump Restoration}

The reclamation of the Strimice dump $(50.533889 \mathrm{~N}, 13.669722 \mathrm{E})$ was the first successful restoration. Its formation ended in 1973. The elevation of the dump reached 330 meters. Former Forestry reclamation was not successful due to severe changes of the surface zone in the dump so the planting died out. At the same time, the great impact of erosion phenomena came to light. Following agricultural reclamation covered 89 ha of the dump surface [5]. Soil profile of the dump consist of upper layer containing mixture of topsoil and bentonite (mineralogy: quartz, kaolinite, illite, and montmorillonite with a mixture of spars and muscovite), a middle layer consisting mixture of clay and bentonite (mineralogy: montmorillonite) and the original material of the dump that consists of yellow clay wit pieces of coal [6]. The upper layer's chemical properties are characterized by neutral soil reaction with medium content of humus, by low content of nitrogen and phosphorus, and medium to high content of $\mathrm{Mg}$ and $\mathrm{K}$. The middle layer's soil reaction is lightly alkaline with increasing calcite content. The nitrogen and humus content is low. The nutrient content is increasing slightly against the upper layer. Grain size of both layers is defined as lightly coarse. Predominantly bentonites were used for soil fertilization. The results prove the success of the method selected for the Strimice dump reclamation. It is shown in Table 2. Given the current market price of bentonite, it is not practically possible to employ this type of reclamation today.

Completed reclamation of the Strimice dump is shown in the Figure 3. There is an airport with a surface of approximately 90 ha that is surrounded by agricultural reclamation. The slopes of the dump, where the forestry reclamation was made, now serve as a recreational area with tourist trails.

\subsection{Radovesice Dump Restoration}

In 1964 the reclamation of Radovesice dump $(50.5582708 \mathrm{~N}, 13.8002164 \mathrm{E})$ began. It is the largest dump in the Czech Republic [7]. Given the size of the dump, and its significance and severe character of the most deposited overburden rocks, there has been an adaptation of the dump surface performed using local

Table 2. Properties of the reclaimed soil profile.

\begin{tabular}{|c|c|c|c|c|c|c|c|c|c|c|}
\hline \multirow{2}{*}{$\begin{array}{l}\text { Probe S1-sample } \\
\text { taking interval (m) }\end{array}$} & \multirow{2}{*}{$\begin{array}{c}\mathrm{N} \\
(\%)\end{array}$} & \multirow{2}{*}{$\begin{array}{l}\text { org. substances } \\
(\%)\end{array}$} & \multirow{2}{*}{$\begin{array}{c}\mathrm{CaCO}_{3} \\
(\%)\end{array}$} & \multirow{2}{*}{$\mathrm{pH} / \mathrm{H}_{2} \mathrm{O}$} & \multicolumn{3}{|c|}{ Receivable nutrients $\left(\mathrm{mg} \cdot \mathrm{kg}^{-1}\right)$} & \multicolumn{3}{|c|}{ Sorption capacity $\mathrm{mmol} / 100 \mathrm{~g}$} \\
\hline & & & & & $\mathbf{P}$ & K & $\mathrm{Mg}$ & $S$ & $\mathrm{~T}$ & V (\%) \\
\hline $0.00-0.60$ & 0.07 & 1.24 & 0.98 & 6.79 & 10 & 190 & 102 & 13.4 & 19.7 & 68 \\
\hline $0.60-0.90$ & 0.07 & 0.68 & 9.93 & 8.23 & 1 & 218 & 949 & 36.3 & 36.3 & 100 \\
\hline Under 0.90 & 0.15 & 2.94 & 0.24 & 4.50 & 1 & 103 & 304 & 3.1 & 8.2 & 39 \\
\hline
\end{tabular}

S: The content of exchangeable basic cations. T: The maximum sorption capacity of the exchangeable basic cations of the soil sample. V: The degree of saturation by basic cations. 


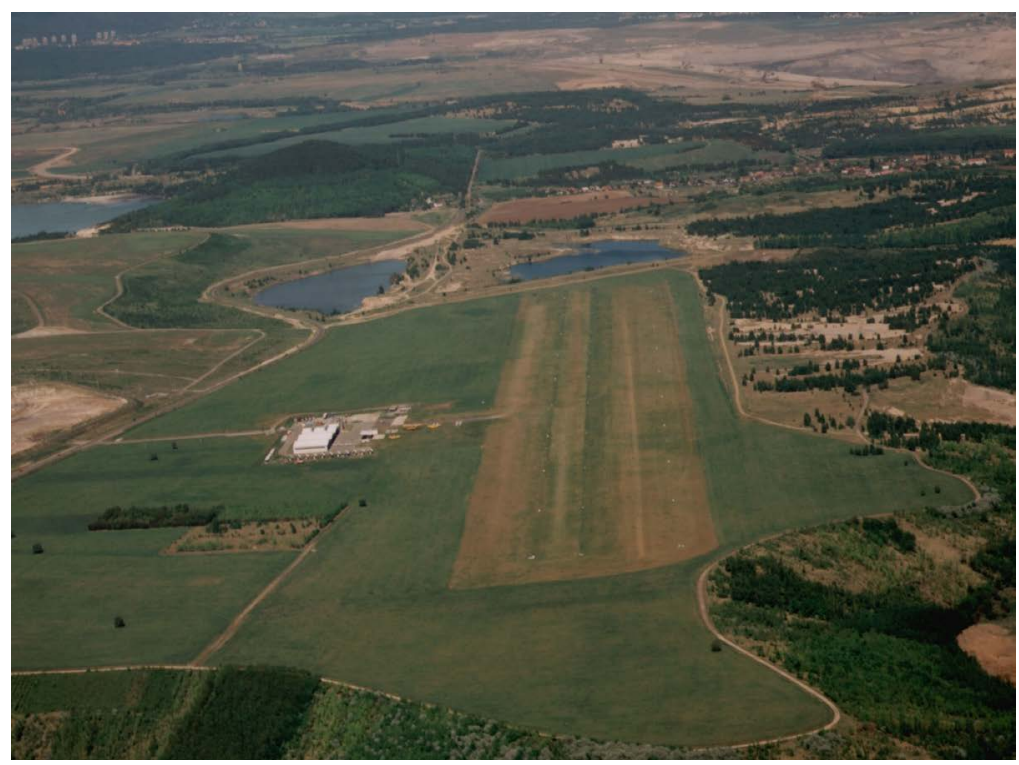

Figure 3. Completed reclamation of the Strimice dump [4].

marlites. These create a geological surface of the eroded valley in the dump bedrock. Marlite mining takes place close to the dump, which substantially decreases the cost of technical reclamation. The dump surface adaptation and reclamation work is performed gradually, after the technical parts of the dump are poured. Shortening the period between dumping and reclamation is of essential importance for shortening the period of weathering of the original material in the dump surface. Pyrite oxidation and clayey rocks disintegration will be avoided. The Radovesice dump surface reclamation starts with bringing $0.3 \mathrm{~m}$ of marlite to the defined area and ploughing under with a cultivator to the depth $0.5-0.7 \mathrm{~m}$. With respect to the dump coal content, the marlite stone type and the requested ploughing depth, it is technically the most demanding phase of reclamation. Overburden materials will rise to the top again with the ploughing; these are then covered with $0.3 \mathrm{~m}$ marlite and ploughed under to a depth of 0.7 1.0 meters. Thus, the originally ploughed-under marlite will get into the mixture and the final mixed rooting horizon is acquired with an actual depth $0.6-1.0$ meters. The properties of the arising rooting horizon are continuously monitored. At present a research of the pilot areas is taking place, where various amounts of marlite are applied using various methodologies (with ploughing under and without), or covered with other rocks. The properties of the newly formed soil profile are shown in Table 3.

After the completed technical reclamation the biological, mostly forestry reclamation is now being done in the area. A suburban park, serving the needs of the citizens of Bilina, will be built in a part of the area. A newly created anthropogenic soil profile is shown in Figure 4.

\subsection{Restoration of the Bilina Mine's Inner Dump}

Most volumes of the extracted overburden rocks of the Bilina mine $(50.5695406 \mathrm{~N}$, 
Table 3. Properties of the reclaimed soil profile.

\begin{tabular}{|c|c|c|c|c|c|c|c|c|c|c|}
\hline \multirow{2}{*}{$\begin{array}{l}\text { Probe S1-sample taking interval } \\
\text { (m) }\end{array}$} & \multirow{2}{*}{ N (\%) } & \multirow{2}{*}{$\begin{array}{l}\text { org. substances } \\
\text { (\%) }\end{array}$} & \multirow{2}{*}{$\begin{array}{c}\mathrm{CaCO}_{3} \\
(\%)\end{array}$} & \multirow{2}{*}{$\mathrm{pH} / \mathrm{H}_{2} \mathrm{O}$} & \multicolumn{3}{|c|}{ Receivable nutrients $\left(\mathrm{mg} \cdot \mathrm{kg}^{-1}\right)$} & \multicolumn{3}{|c|}{ Sorption capacity $\mathrm{mmol} / 100 \mathrm{~g}$} \\
\hline & & & & & $\mathbf{P}$ & $\mathrm{K}$ & $\mathrm{Mg}$ & $S$ & $\mathrm{~T}$ & V (\%) \\
\hline $0.00-0.30$ & 0.12 & 0.83 & 9.41 & 7.93 & 1 & 148 & 96 & 16.8 & 16.8 & 100 \\
\hline $0.30-0.90$ & 0.09 & 0.44 & 39.42 & 8.25 & 0 & 112 & 26 & 15.6 & 15.6 & 100 \\
\hline under 0.90 & 0.10 & 1.03 & 1.07 & 7.90 & 0 & 196 & 269 & 7.9 & 7.9 & 100 \\
\hline
\end{tabular}

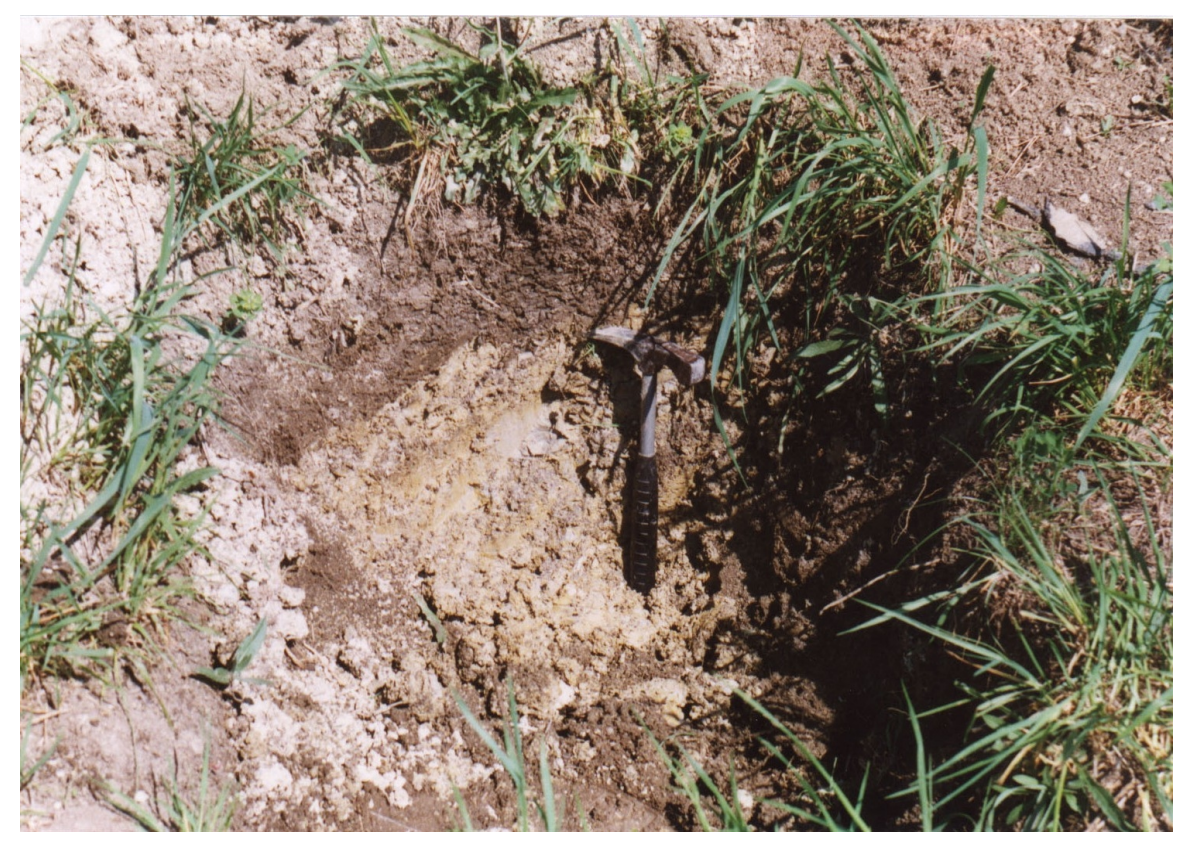

Figure 4. Anthropogenic soil profile in the Radovesice dump [4].

13.7315536E) are now being dumped in the inner dump of the mine. That is why its reclamation was only commenced in the 1990s. It is an example of the successful application of loess and loess loams. The construction of the dump began in the years 1979-1980, and the total expected surface is 1400 ha. A survey of the site was carried out in the years 1997-2003. Based on the requirements of the fertilizable soil and rock methodology, the types of rocks occurring in the body of the dump and the areas with the need of loess application were defined based on the knowledge of the overburden rocks' properties in the Bilina mine [8]. In accordance with the methodology of fertilizable soil and rocks use, loess and loess loams in a quantity of $1500-2000 \mathrm{~m}^{3} \cdot \mathrm{ha}^{-1}$ were applied to the area with the planned forestry reclamation. That was mixed with the dump soil by cross ploughing to a depth of $0.3-0.4 \mathrm{~m}$. The maximum slope of the reclaimed surface was $16 \%(1: 6)$. Compost with an adjusted ratio C: $N$ (25) in a quantity of 400 $\mathrm{t} \cdot \mathrm{ha}^{-1}$ was applied as a complementary reclamation measure, integrated into 0.30 $\mathrm{m}$ of the reclaimed dump surface, after which the follow up two year preparatory agrocycle commenced (growing crops for green fertilisation). The properties of the soil profile after loess application are shown in the Table 4.

Only loess and loess loams from the mine forefront is used for the reclamation 
Table 4. Properties of the reclaimed soil profile.

\begin{tabular}{|c|c|c|c|c|c|c|c|c|c|c|}
\hline \multirow{2}{*}{$\begin{array}{l}\text { Probe S1-sample taking interval } \\
\qquad(\mathrm{m})\end{array}$} & \multirow{2}{*}{$\begin{array}{c}\mathrm{N} \\
(\%)\end{array}$} & \multirow{2}{*}{$\begin{array}{l}\text { org. substances } \\
\text { (\%) }\end{array}$} & \multirow{2}{*}{$\begin{array}{c}\mathrm{CaCO}_{3} \\
(\%)\end{array}$} & \multirow{2}{*}{$\mathrm{pH} / \mathrm{H}_{2} \mathrm{O}$} & \multicolumn{3}{|c|}{ Receivable nutrients $\left(\mathrm{mg} \cdot \mathrm{kg}^{-1}\right)$} & \multicolumn{3}{|c|}{ Sorption capacity $\mathrm{mmol} / 100 \mathrm{~g}$} \\
\hline & & & & & $\mathbf{P}$ & $\mathbf{K}$ & $\mathrm{Mg}$ & $S$ & $\mathrm{~T}$ & $\mathrm{~V}(\%)$ \\
\hline $0.00-0.35$ & 0.08 & 1.15 & 4.78 & 7.25 & 4 & 267 & 1055 & 14 & 14 & 100 \\
\hline $0.35-0.60$ & 0.02 & 2.13 & 0.47 & 7.14 & 1 & 21 & 683 & 7.6 & 9.3 & 81.7 \\
\hline
\end{tabular}

of the Bilina mine. After the soil profile modification ends, forestry and agricultural reclamation will be performed in the dump. After the completion of the hydrological reclamation in the mine and the mine lake formation, beaches and other recreational spaces for the Bilina citizens's recreation will be created in the off-shore parts of the dump.

\section{Conclusion}

The report is concentrated on the history, present and perspective of mining and reclamation in the north-western bohemia region. Reclamation work has been developing based on the extent of coal mining, and now maximum attention is devoted to it. The subject of the research is to evaluate the reclamation availability of overburden rocks from opencast mines in the region, the research of the upper horizon of the dumps, and a proposal for the best methodology of reclamation processes in the localities. The success rate of these procedures is proven by the results achieved in the reclamation of selected important localities in the North-Bohemian Basin. The scientific use of the fertilizable rocks, mainly topsoil, marlites, loess, loess loams and bentonite, is today typical for the Bilina mines whose area, in terms of the complexity of the reclamation work, is the most demanding. But the available types of fertilizable rocks are used in all the sites today. According to the observations and the analysis results it was possible, using the selected method of reclamation, to diminish the impact of erosion, and adjust the chemical status and physical structure of the Radovesice and Strimice dump surfaces. By applying marlite and bentonite, we succeeded in avoiding adverse weathering processes in the dump surfaces. Basically, the quaternary sediments were artificially replaced. In the Radovesice dump the need for marlite plough under and the application of organic substrate was proven. The success of the loess and loess loam application was demonstrated in the inner dump of the Bílina mine. The results show the need for a differentiated approach to the localities, based on the comprehensive analysis of the research work and the scientific concept of the future use of the site. This is the only way to differentiate the best localities for direct biological reclamation from the sites where principal adaptation of the upper horizon is necessary. The achieved results also prove that a knowledge of the properties of the relocated rocks and all natural relations in the area helps to find a solution which limits the negative impacts on the environment. Thanks to the thorough research works and individual approach towards the localities, the dumps in the Most Basin will be successfully integrated into the surrounding landscape. 


\section{Acknowledgements}

This article was supported by project QJ1520307 entitled "Sustainable Forms of Management in an Anthropogenically Burdened Region.” This project was realized with financial support from state budget resources through the KUS program, Ministry of Agriculture of the Czech Republic.

\section{References}

[1] History of Litvinov and Its Surroundings (2011) Nature of the Most RegionClimte.

http://litvinov.sator.eu/kategorie/krusnohori/krusnohori-priroda/priroda-mostecka.

[2] Rehor, M. and Lang, T. (2006) Historical Mineralogical Findings in the Wider Area of North Bohemian Lignite Basin. Research Institute for Brown Coal in Most. http://slon.diamo.cz/hpvt/2006/tradice/T01_rehor.htm.

[3] Cermák, P. (1993) Evaluation Methodology for the Erosion Protection of Dump Soil and Vegetative or Other Treatment in North-Bohemian Brown Coal District, Report. Research Institute of Soil Improvement and Soil Protection, Prague. 65 p.

[4] Rehor, M. (2005) Overburden Cuts in the Bílina Mine, Author's Own Photography.

[5] Rehor, M., et al. (1996) Application of Modern Restoration Methods in the Localities of the Bílina Mines, Proceedings II. Of International Congress of Brown Coal, Wroclaw.

[6] Rehor, M. (1994) Research of Overburden Soil Suitability for Reclamation, Expert Opinion. Institute of Soil Improvement and Soil Protection, Prague, $14 \mathrm{p}$.

[7] Fisera, E., et al. (1992) Integration of the Radovesice Dump into the Area's Ecosystem, Abstract. Conference: Reclamation Construction Most.

[8] Rehor, M., et al. (2002) Use of Accessory Material Acquired in Opencast Mining of Brown Coal Deposits for Reclamation of These Sites, Abstract, Mining Univerzity in Ostrava. 